\title{
THREE JOINS FROM THE ZENON ARCHIVE
}

\section{FRAGMENT OF A LETTER}

P. Brit. Libr. 2357C + P. Cairo ined.

P. Lond. VII $2098+$ Ms. Edgar, p. 12 no. 3

$7.9 \times 8.8 \mathrm{~cm}$

$8 \times 11 \mathrm{~cm}$ date unknown

The text is written across the fibres in a small hand, which is comparable but not identical with that of Zenon himself.

Even after the joining of the two fragments too much is lost to obtain a comprehensible text. If the roll was about $30 \mathrm{~cm}$ in width, about a third must be missing. But perhaps the present publication will allow someone else to retrace one of the fragments missing to the left and to the right.

The traces at the bottom of the London fragment reflect in mirror writing the last line of the text (one recognizes the word $\mu \varepsilon \tau \alpha \beta \alpha \lambda \mathrm{ov}$ ). Apparently the last words were not yet dry when the letter was folded.

The fragment to the right (photograph on p. 6) is now in the British Library. The left fragment is now in Cairo; I know it only through the transcript in a notebook of C.C. Edgar, which was put at my disposal by T.C. Skeat many years ago. Most of the texts in that notebook are gradually being published by prof. Zaki Aly.

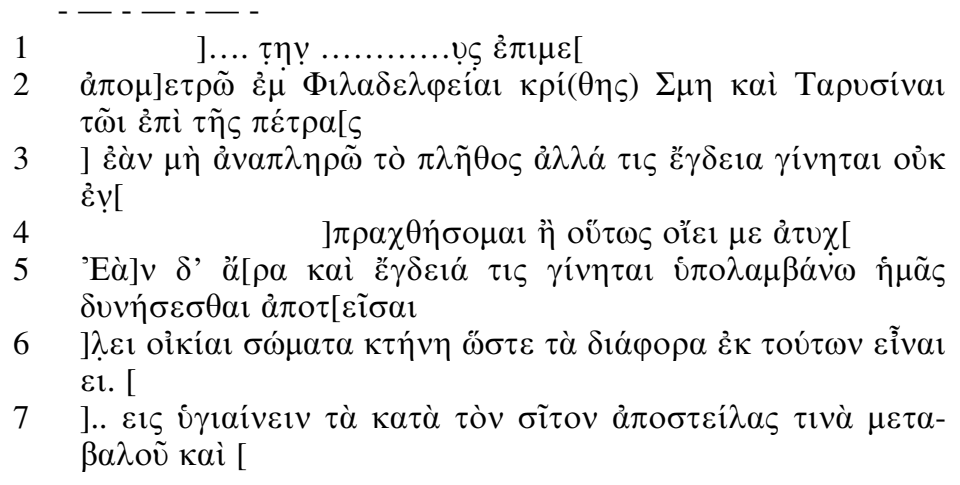

so that I will] measure in Philadelpheia 248 (artabas of) barley and to Tarusinas, who is in charge of the Rock [.. artabas, total.. artabas of barley (?)]. If I cannot pay in full the amount, but some deficit occurs, 


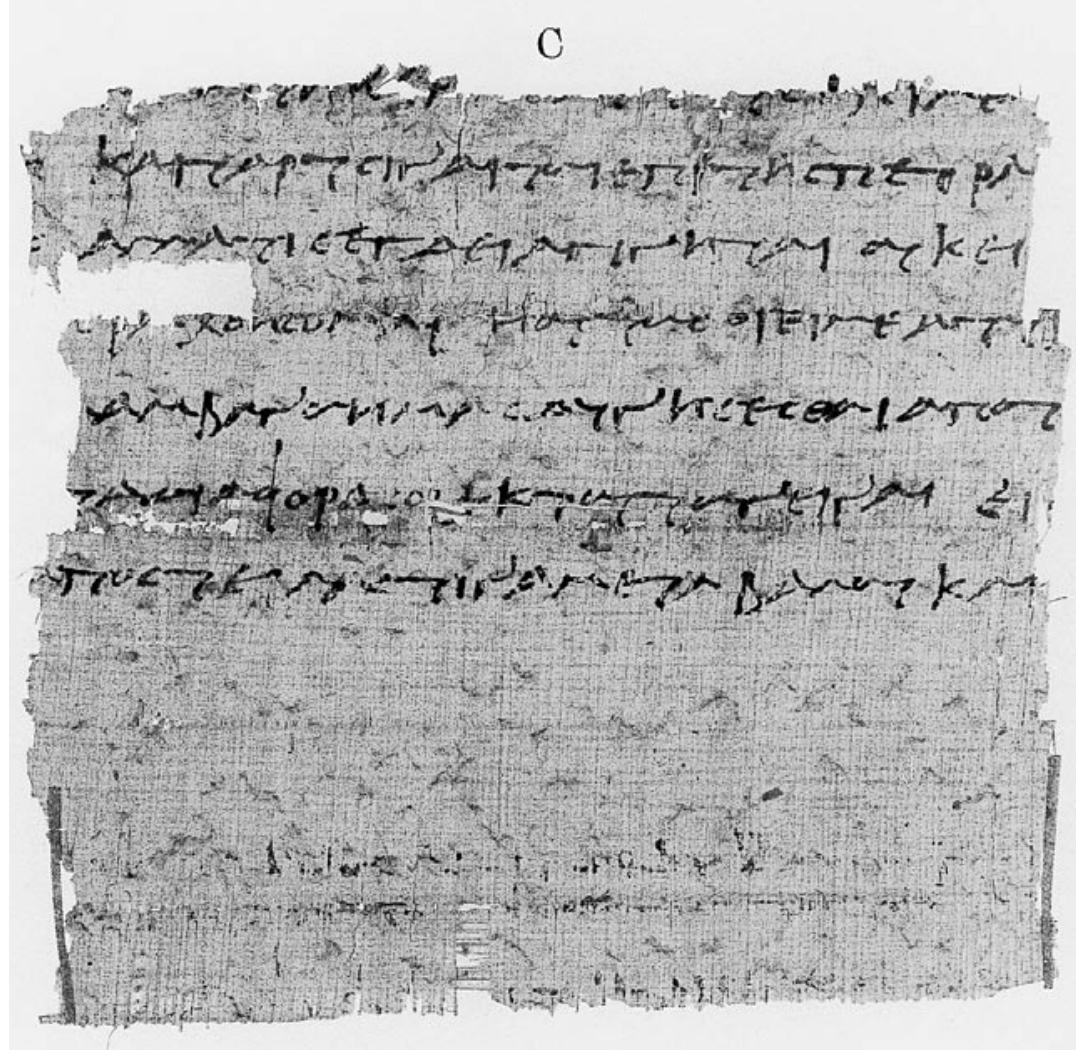

By permission of the British Library - Pap. 2357C

I will not [- -]. Payment will be exacted from me or do you think that I am so unfortunate [that - - - ]. If however some deficit occurs, I suppose that we will be able to pay [- - - houses, slaves, cattle so that the cash may be derived from them. [- - - if therefore you want to ascertain (?)] that the affairs concerning the grain are all right, send somebody and transfer (the grain) and [

2. The verb $[\dot{\alpha} \pi \circ \mu] \varepsilon \tau \rho \tilde{\omega}$ is probably a subjunctive form depending on a conjunction such as ív or ö $\pi \omega s$.

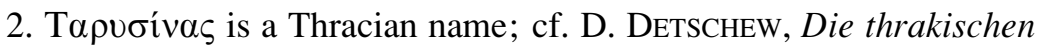
Sprachreste, 1957, p. 491; see also SEG XLII (1992), nos. 580-583 pas-

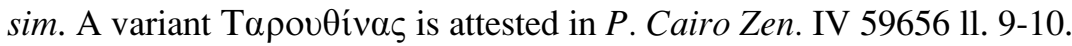
This may be the same person, cf. P.L. Bat. XXI, p. 425. It is just possible that the name turns up again in a demotic text, $P$. Lille dem. III 99 verso col.5 1. 31. F. de Cenival reads here Tryqynws as the name of a slave in 
a Greek cleruchic family. Several suggestions have been put forward for the underlying name: Drakon, Dorkinos, Dorigenes, Trichinos, none of them convincing. As often happens in demotic, the difference between $q$ and $t$ is very small and a reading Trytynws seems possible. A Thracian name for a slave would not surprise in the Hellenistic period. There is, however, a minor orthographical problem: instead of Trytynws one expects Trwtynws. Although in foreign names this kind of irregularity is rather frequent, I can offer this interpretation only as a suggestion.

Tarusinas' function in the present text is unclear. The «rock» may be the name of some kind of quarry, as the word is also used in the archive of the architekton Kleon, perhaps as a kind of toponym (P. Petrie III 43.2 col. 21.13 [p. 119]).

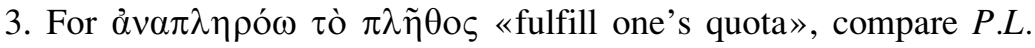
Bat. XX 56A 1. 8.

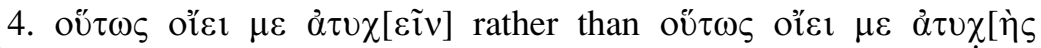
Eĩ̃val] (thus indexed in P.L. Bat. XXI, p. 604). Neither the verb $\dot{\alpha} \tau \cup \chi \varepsilon \tilde{\imath} v$

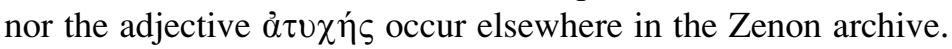

5. For the use of غ̇àv ö $\rho \alpha$, see E. MAYSER, Grammatik II 3, p. 120.

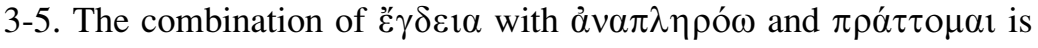

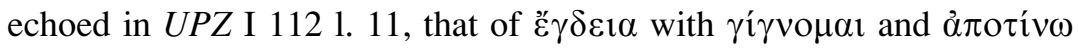

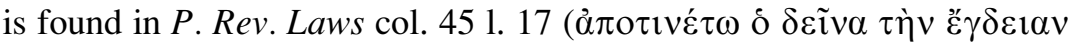

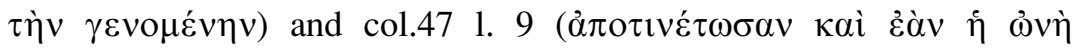
$\ddot{\varepsilon} \gamma \delta \varepsilon ı \alpha \nu \pi$ oiñ). These parallels suggest that the present text has to do with tax farming.

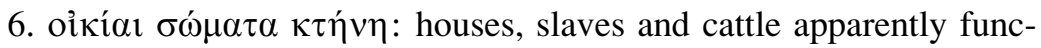
tion as mortgage for the payments the writer has taken upon him: if he

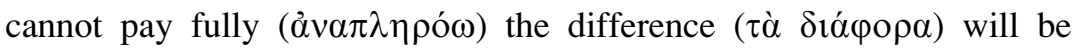
made up from his possessions. The asyndetic juxtaposition of the three words gives the impression of a fixed formula, but the combination is hardly attested elsewhere. In Greek only two parallels can be given, both

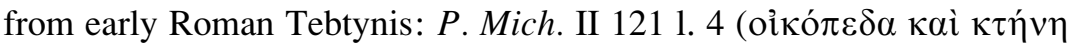

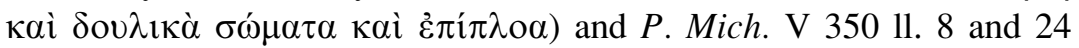

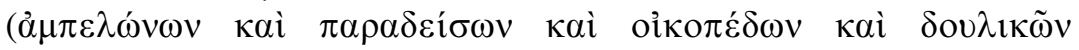

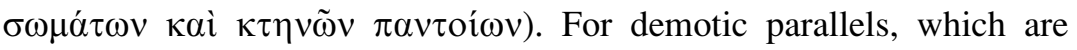
much more common, a full survey is given by S.P. VLEEMING, The Goose Herds of Hou (Studia Demotica, 3), Leuven 1991, p. 173 note qq.

6 . The word $\delta 1 \alpha \varphi \circ \rho \alpha$ is wrongly listed as $\eta \dot{\eta} \delta 1 \alpha \varphi \rho \rho \alpha$ in the index of P. Lond. VII and P.L. Bat XXI, p. 620. The new fragment clearly shows it is a plural of $\delta$ iópopov. 
7. Skeat read $\mu \varepsilon \tau \alpha \beta \alpha ́ \lambda \omega 1$, with a superfluous iota. The groups ov and $\omega 1$ are very similar in this hand, as can be seen when $\tau \omega \iota$ in 1.2 is compared with oủ $\kappa$ in 1.3 and $\tau$ oú $\tau \omega \mathrm{v}$ in 1. 6. Iota is more straight, whereas the leg of ypsilon is curved. Our correction removes an orthographical problem: as I have shown elsewhere ( $C E$ 50, 1976, p. 150-166, where this passage is discussed on p. $165 ; B O 40,1983$, p. 81-86), irregularities in the use of iota adscript after alpha and omega are extremely rare before the end of the 3rd cent. BC. For the middle $\mu \varepsilon \tau \alpha \beta \alpha$ ' $\lambda \lambda \circ \mu \alpha 1$, compare P. Hib. I 42 11. 3 and 8 and 45 1. 6.

Katholieke Universiteit Leuven

Willy CLARYSSE

\section{UN UNICO CONTO DELL'ARCHIVIO DI ZENONE*}

\section{P. Cair. Zen. I $59112+$ PSI V 545}

Se si scorrono le pagine 4-71 del Guide to the Zenon Archive ${ }^{1}$, in cui sono elencati i testi del dossier zenoniano, si trovano decine di papiri che sono stati ricomposti ricongiungendo due o più frammenti, talvolta conservati in collezioni diverse. La situazione non potrebbe essere differente, perché il materiale fu ritrovato da scavatori locali, i papiri rimasero sul mercato per parecchi anni e pezzi di vari reperti, già rotti al momento del recupero o frantumatisi successivamente a causa delle manipolazioni subite, furono frequentemente venduti ad acquirenti diversi ${ }^{2}$. Quindi non

* Esprimo la mia gratitudine al dott. Mohamed Abdel Hamid el-Shimy, direttore del Museo Egizio del Cairo, e alla dott.ssa Franca Arduini, direttrice della Biblioteca Medicea Laurenziana, che mi hanno autorizzato a pubblicare le immagini di P. Cair. Zen. I 59112 e di PSI V 545. Ringrazio, inoltre, il prof. Willy Clarysse, che mi ha fornito una riproduzione del reperto conservato al Cairo.

1 P.W. Pestman et all., A Guide to the Zenon Archive (= P. L. Bat. XXI), Leiden 1981 (d'ora in poi cit. Guide).

2 Sul recupero dell' archivio e sul passaggio di esso attraverso il commercio antiquario cf. P. Mich. I, p. 1s.; E. BRECCIA, Egitto greco e romano, Pisa 1957³, p. $113 \mathrm{ss}$; Cl. OrRIEUX, Zénon de Caunos, parépidèmos, et le destin grec, Paris 1985, p. 41ss. Relativamente a $P$. Cair. Zen. I 59112 e PSI V 545, di cui si tratta in queste pagine, purtroppo non è possibile precisare quando siano entrati nelle collezioni del Cairo e di Firenze. Per il $P$. Cair. Zen. il Journal d'Entrée del Museo Egizio rivela soltanto che esso fu registrato il $15 / \mathrm{X} / 1924$, sotto il nr. 48560, insieme ad un gruppo di documenti zenoniani «acquired at various times from 1915 onwards, chiefly by purchase from M. Nahman» (cf. Journal d'Entrée X, ad 48448-48588). Del pezzo fiorentino, invece, si sa appena che esso fu comprato da Guido Gentilli prima della sua scomparsa avvenuta nell'estate del 1916: cf. PSI IV, p. VIIs. e $P S I \mathrm{~V}, \mathrm{p}$. VI. 


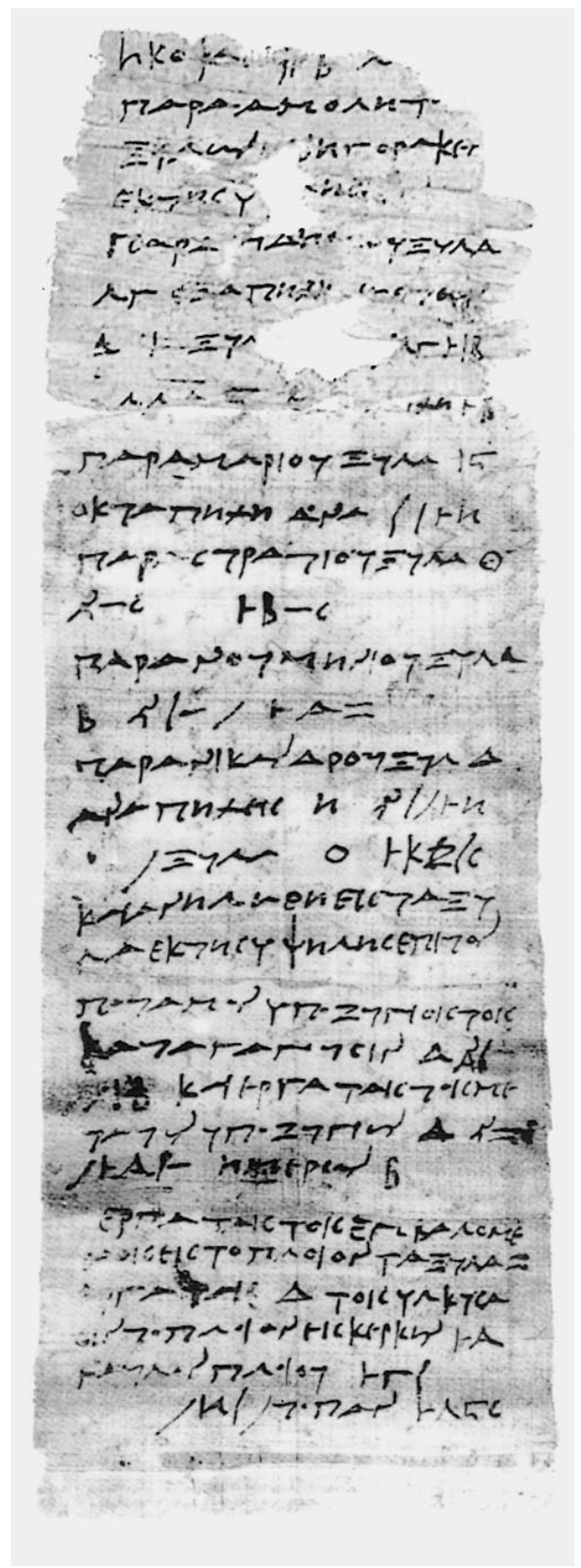


ci si stupisce constatando che anche P. Cair. Zen. I 59112 e PSI V 545 altro non sono che due parti di un unico documento: il pezzo cairense contiene le righe iniziali del testo, quello fiorentino la sezione restante, senza che nessuna linea sia andata persa tra i due frammenti. L'ultima riga del P. Cair. Zen. e la prima del PSI, entrambe danneggiate, si completano a vicenda e si combinano in un'unica linea intatta, nella quale si legge ợ $\lambda \lambda \alpha \varsigma \dot{\varepsilon} \xi \alpha \underset{\eta}{\prime} \chi \eta(\delta \rho$.) $\beta$. La sillaba iniziale è conservata dal pezzo del Cairo, mentre i segni conclusivi sono rimasti su quello fiorentino; ma alcune lettere ed una cifra sono divise tra un papiro e l'altro:

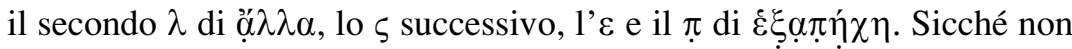
vi è incertezza alcuna sulla ricongiunzione dei frammenti.

Unificati i due pezzi, si ottiene un unico foglio di cm. $10 \times 28,8$, che porta un conto di 30 righe relativo ad un approvvigionamento di legname. All'inizio abbiamo la data, la menzione della persona che aveva effettuato gli acquisti, e la precisazione che il materiale veniva da Hypselé, cioè dal nomo Memphites (1l. 1-4). Alla 1. 5 iniziano le registrazioni in dettaglio delle spese, con la segnalazione del numero dei pali comprati presso i vari fornitori e con l'indicazione del prezzo per essi pagato (11. 5-17). Successivamente si annotano le spese relative al trasporto del legname, che prima fu trasferito per via di terra da Hypselé al Nilo (11. 18-24), poi fu fatto risalire per via fluviale sino all'approdo di Kerké (ll. 25-29). Infine, nell'ultima riga, si segna l'importo complessivo dell'operazione (1. 30).

Siccome è datato al 2 Phaophi del XXIX anno del Filadelfo (26 novembre 257 a.C.), il conto deve essere inserito nel cosiddetto dossier di Panakestor, cioè in quel gruppo di testi dell'archivio, collocati fra il 257 e il 256 a.C., che riguardano la gestione della $\delta \omega \rho \varepsilon \alpha ́$ nel periodo precedente alla nomina di Zenone come amministratore ${ }^{3}$. Fatta questa prima constatazione, si può anche notare che la destinazione finale del legno comprato a Hypselé sembra essere Kerké. Se, infatti, i pali avessero dovuto andare a Memphis o ad Alessandria, non sarebbero stati fatti risalire sul Nilo da Hypselé a Kerké per poi farli scendere di nuovo verso il Delta. Analogamente, se il materiale fosse stato destinato a Philadelphia, nel conto troveremmo registrate le spese relative al trasporto per via di terra da Kerké al villaggio. Poiché Kerké costituiva uno dei principali attracchi della flottiglia fluviale di Apollonio ed era la sede di

${ }^{3}$ Cf. Guide, p. 175; Cl. Orrieux, Zénon (nt. 2), p. 44. 
cantieri nautici ${ }^{4}$, non è arrischiato pensare che il legname là destinato dovesse servire alla costruzione o alla riparazione di battelli.

Del testo ottenuto ricongiungendo $P$. Cair. Zen. I 59112 e PSI V 545 si fornisce qui sotto una trascrizione integrale, anche se solo la metà iniziale di esso presenta cambiamenti rispetto alle precedenti edizioni. Così facendo si vuole agevolare il lettore nella comprensione del conto; nello stesso tempo si approfitta dell'occasione per chiarire qualche dettaglio del contenuto su cui non si erano soffermati i commenti annessi alle prime edizioni ${ }^{5}$.

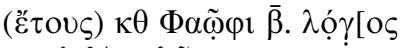

$\pi \alpha \rho \grave{\alpha}^{\prime} \mathrm{A} \mu \mathrm{o} \lambda \tilde{\eta} \tau[\mathrm{o} \varsigma$

$\xi u ́ \lambda \omega \nu$ ติ้

$\dot{\varepsilon} \kappa \tau \tilde{\eta}{ }^{e} Y \psi[\eta] \lambda \tilde{\eta} s$.

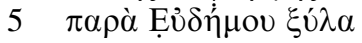

$\lambda \gamma \dot{\varepsilon} \xi \alpha \pi \eta \dot{\chi} \chi, \omega \varsigma \tau \tilde{\omega} \nu$

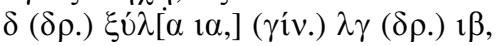

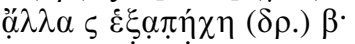

$\pi \alpha \rho \alpha ̀$ Máíou $\xi u ́ \lambda \alpha$ is

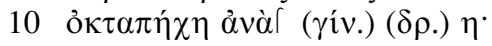

$\pi \alpha \rho \alpha \grave{\Sigma} \Sigma \rho \alpha \tau i ́ o v ~ \xi u ́ \lambda \alpha \theta$

$\dot{\alpha} v(\grave{\alpha})-c\langle(\gamma i ́ v)\rangle.(\delta \rho.) \beta-c^{\prime}$

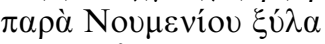

$\beta \dot{\alpha} v(\grave{\alpha}) f(\gamma i ́ v).(\delta \rho.) \alpha=$.

$15 \pi \alpha \rho \alpha \grave{~ N i \kappa \alpha ́ v \delta \rho o v ~ \xi u ́ \lambda(\alpha) \delta ~}$

$\dot{\alpha} v \grave{\alpha} \pi \eta \dot{\chi} \chi \varepsilon 1 \varsigma \eta \dot{\alpha} v(\grave{\alpha})\lceil(\gamma i ́ v).(\delta \rho.) \eta$.

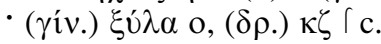

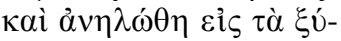

$\lambda \alpha \dot{\varepsilon} \kappa \tau \tilde{\eta} \varsigma{ }^{e} Y \psi \eta \lambda \tilde{\eta} \varsigma \dot{\varepsilon} \pi \grave{i} \tau o ̀ v$

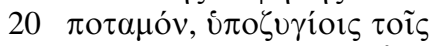

$\kappa \alpha \tau \alpha \gamma \alpha \gamma \circ \tilde{0} \sigma ı v \delta \dot{\alpha} v(\grave{\alpha}) \Gamma$

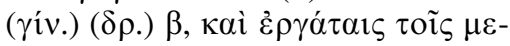

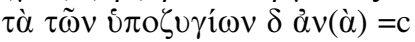

( $\left.\gamma^{\prime} v.\right)(\delta \rho.) \alpha f, \tilde{\eta} \mu \varepsilon \rho \tilde{\omega} v \beta$.

${ }^{4}$ Cf. M. RostovtzefF, A Large Estate in Egypt in the Third Century B.C., Madison 1922, p. 122ss.; Cl. PrÉAuX, Les Grecs en Egypte d'après les archives de Zénon, Bruxelles 1947, p. 29.

${ }^{5}$ Dopo l'ed. $p r$. né il $P$. Cair. Zen. né il $P S I$ hanno attratto molte attenzioni: il primo ha avuto una correzione in $C E 43$ (1968), p. 168 (= BL VI, p. 27), il secondo è stato rapidamente descritto e riprodotto in G. Messeri Savorelli - R. Pintaudi, I papiri dell'archivio di Zenon a Firenze (= Pap. Flor. XXIV), Firenze 1993, p. 57 e tav. XLIII. 
$25 \dot{\varepsilon} \rho \gamma \alpha \dot{\alpha} \tau \alpha 1 \varsigma \tau$ oĩ $\dot{\varepsilon} \mu \beta \alpha \lambda \mathrm{o} \mu \dot{\varepsilon}-$

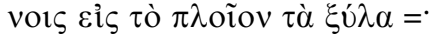

$\dot{\varepsilon} \rho \gamma \alpha \dot{\tau} \tau \alpha 1 \varsigma \delta \tau$ oĩ $\tilde{u} \lambda \kappa u ́ \sigma \alpha-$

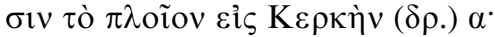

vaṽ $\lambda$ ov $\pi \lambda$ oíov $(\delta \rho.) \gamma\lceil\cdot$

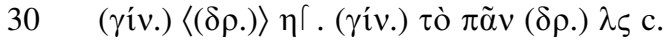

$16(\delta \rho.) \eta \operatorname{pro}(\delta \rho.) \beta$

27-28l. $\varepsilon \lambda \kappa u ́ \sigma \alpha \sigma \mathrm{v}$

Anno XXIX, 2 di Phaophi. Conto presentato da Amoles per i pali che ha comprato a Hypselé.

Da Eudemos, 33 pali di sei cubiti al prezzo di 4 dracme per 11 pali, fanno pali 33, dr. 12.; altri 6 pali di sei cubiti, dr. 2;

da Marios, 16 pali di otto cubiti al prezzo di 3 oboli l'uno, fanno dr. 8; da Stratios, 9 pali al prezzo di ob. 1 1/2 l'uno, fanno dr. 2 ob. 1 1/2; da Numenios, 2 pali al prezzo di 4 ob. l'uno, fanno dr. 1 ob. 2 ;

da Nikandros, 4 pali della lunghezza di 8 cubiti al prezzo di 3 ob. l'uno, fanno dr. 8 ( sic).

Fanno pali 70, dr. 27 ob. 3 1/2.

E per il trasporto dei pali da Hypselé al fiume si è speso:

per gli animali che li hanno portati giù, 4 al costo di 3 ob. l'uno, fanno

dr. 2, e agli operai che hanno condotto gli animali, 4 al costo di ob.

2 1/2 l'uno, fanno dr. 1 ob. 4, per 2 giorni;

agli operai che hanno caricato i pali sul battello, ob. 2;

ai 4 operai che hanno trainato il battello a Kerké, dr. 1;

nolo del battello, dr. 3 ob. 3 .

Fanno dr. 8 ob. 3. Fanno in totale dr. 36 ob. 1/2.

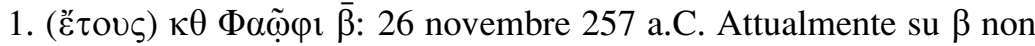
si scorge contrassegno alcuno; ma è assai probabile che in origine un' asta orizzontale fosse posta sopra il numero indicante il giorno, come era consueto. Essa poi andò perduta a causa dell'erosione che guastò il margine superiore del foglio e parte della riga iniziale.

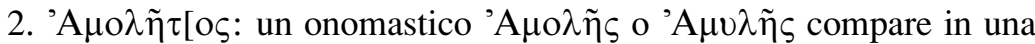
decina di documenti dell'archivio: cf. Guide, p. 283. Ma, per quanto esso non sia troppo ricorrente, non è agevole stabilire se indichi sempre la stessa persona oppure designi individui diversi. L'unico personaggio con tale nome identificabile con sicurezza è un certo Amoles figlio di Herpekysis (o Herpechysis), citato con il suo patronimico in P. Cair. Zen. IV 59549, 2, 8 (257 a.C.), PSI VI 560, 6 (cf. Guide, p. 150; 257/6 a.C.) e P. Col. Zen. I 27, 2,7 (cf. ibid., p. 124; 256 a.C.) dove compare come destinatario di pagamenti fatti per la disinfestazione di terreni dalla macchia, e in P. Cair. Zen. II 59173, 40 (255/4 a.C.) dove figura come testimone. In Guide, p. 283, si definisce «farmer» questo Amoles di 
Herpekysis e si segnala che egli probabilmente è menzionato pure in altri testi dell'archivio dove il patronimico non compare accanto al nome: i conti di P. Cair. Zen. II 59292 (ll. 373, 602; 250 a.C.), IV 59748 (1. 56) e P. Mich. I 119 (1. 39), in cui un Amoles è citato o come destinatario o come intermediario di pagamenti; la lista di persone di $P$. Cair. Zen. IV 59656 (1. 13); la lettera di P. Cair. Zen. III 59381; forse la ricevuta di P. L. Bat. XX 8 (cf. nt. d; 257 a.C.) e P. Cair. Zen. I 59112, cioè il testo qui riedito. L'ipotesi che tutti questi documenti possano essere assegnati allo stesso Amoles di Herpekysis è senza dubbio attraente; ma, prima di accettarla, è opportuna qualche cautela, almeno per quanto riguarda il conto qui trascritto. L'acquisto e il trasporto del legname, infatti, dovevano rientrare nelle competenze dei dipendenti della $\delta \omega \rho \varepsilon \alpha ́$, non in quelle dei contadini. Quindi non è molto verosimile che l'individuo nominato nella presente riga sia Amoles figlio di Herpekysis, perché nel 257/6 a.C. quest'ultimo non era un impiegato dell'azienda: egli curava la pulitura di terreni del latifondo, facendo lavorare altra gente con sé e incassando un compenso forfetario per ogni arura sistemata. Volendo, si potrebbe pensare che l'amministratore Panakestor, o qualche suo collaboratore, abbia incaricato l'Amoles figlio di Herpekysis di procurare dei pali, per quanto egli fosse al di fuori dell'azienda. Una simile eventualità non è del tutto esclusa; ma sembra poco probabile che la stessa persona potesse occuparsi contemporaneamente della disinfestazione dei terreni a Filadelfia (cf. P. Cair. Zen. IV 59549: anno XXIX, Phaophi 27) e dell'acquisto del legname nel nomo Memphites (cf. 1. 1: anno XXIX, Phaophi 2). Davanti a queste difficoltà è meglio lasciare indeterminata l'identificazione del personaggio qui menzionato.

4. ${ }^{\circ} Y \psi[\eta] \lambda \tilde{\eta} \varsigma: ~ v ̋ \lambda \eta \varsigma P$. Cair. Zen. I 59112. La traccia rimasta dopo $v$ nella parte più bassa del rigo e le dimensioni della lacuna, che separa lo stesso $v$ dal successivo $\lambda$, rendono sufficientemente sicura la trascrizione ${ }^{e} Y \psi[\eta] \lambda \tilde{\eta} \varsigma$ suggerita da 1. 19. Con la nuova lettura proposta si ottiene

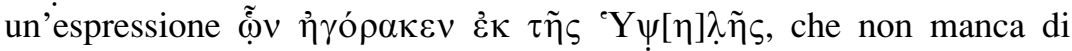
paralleli nei documenti dell'archivio: cf. ex. gr. P. Cair. Zen. IV 59595, 8 e $P$. Mich. I 28, 15.

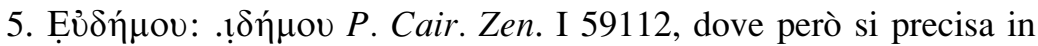

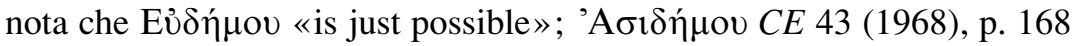
(=BL VI, p. 27). I resti della lettera iniziale ben si adattano ad un $\varepsilon$,

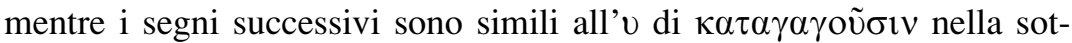
tostante 1. 21; sicché non è arrischiato leggere Eủoń 
9. Mapíov: non è il caso di ritenere che il nome Mápıos qui rappresenti l'equivalente greco del latino Marius, giacché è poco probabile che alla metà del III sec. a.C. vi fossero dei latini insediati nel nomo Memphites. Mápıos, piuttosto, deve essere considerato come la trascrizione greca dell'antroponimo aramaico מד, accogliendo le conclusioni tratte in $C P J$ I 47,3 nt.

16. ( $\gamma^{\prime} v$.) $(\delta \rho.) \eta$ : il costo complessivo dei 4 pali comprati presso Nikandros a 3 oboli l'uno era di 2 dracme, non di 8; pertanto qui dovrebbe comparire $\beta$ al posto di $\eta$. L'anomalia, comunque, non deriva da un errore di calcolo, perché nel totale di 1.17 (dr. 27 ob. 3 1/2) i pali di Nikandros sono correttamente conteggiati per l'importo di 2 dracme. La sostituzione di $\beta$ con $\eta$ è piuttosto dovuta ad uno sbaglio di trascrizione, commesso quando il conto fu steso in forma definitiva, ricopiando i prezzi delle singole forniture forse già annotati altrove al momento dell'acquisto o del pagamento del materiale: la presenza della cifra $\eta$ nell'indicazione della lunghezza dei pali, poco prima di ( $\gamma i ́ v$.) $(\delta \rho$.), può aver prodotto lo scambio fra $\eta$ e $\beta$ nella registrazione del costo complessivo.

17. Il grosso punto che precede i due totali deve essere inteso come un segno di controllo, che fu apposto quando la somma spesa venne trascritta in un rendiconto generale, oppure quando fu fatta qualche verifica o sulla quantità del legname comprato o sull'importo per esso pagato.

$\xi u ́ \lambda \alpha$ o: il numero complessivo dei pali è esatto: $33(1.7)+6(1.8)+$ $16(1.9)+9(1.11)+2(11.13-14)+4(1.15)=70$.

$(\delta \rho.) \kappa \zeta\lceil\mathrm{c}: \zeta$ è stato tracciato su un simbolo $\Upsilon$ forse banalmente anticipato per un errore di trascrizione. Il totale delle somme pagate per le singole forniture è preciso ed include correttamente 2 dracme, anziché 8 , per i pali acquistati presso Nikandros (cf. nt. ad l. 16): dr. $12(1.7)+\mathrm{dr}$. $2(1.8)+$ dr. $8(1.10)+$ dr. 2 ob. $11 / 2(1.12)+$ dr. 1 ob. $2(1.14)+$ dr. 2 (1. 16) $=$ dr. 27 ob. $31 / 2$.

30. $(\delta \rho)>.\eta \uparrow$ rappresenta il totale dei costi sostenuti per il trasporto del legname, che sono annotati a 11. 18-29: dr. 2 (1. 22) + dr. 1 ob. 4 (1. 24) + ob. $2(1.26)+$ dr. $1(1.28)+$ dr. 3 ob. $3(1.29)=$ dr. 8 ob. 3 .

Con $(\delta \rho.) \lambda \varsigma \mathrm{c}$ si indica l'ammontare complessivo delle spese registrate, che risulta dalla somma del prezzo pagato per il legname (1. 17: dr. 27 ob. 3 1/2) e del costo del trasporto (dr. 8 ob. 3 ). 


\section{P. Cair. Zen. I $59014 \mathrm{a}$ and b}

In his edition of the Zenon papyri, Edgar recognized that the previously published PSI VII 867 belonged to a Cairo fragment. Thus he published both of them as P. Cair. Zen. I 59014; PSI VII 867 became known as fragment (a), and the Cairo piece as (b). Edgar apparently never saw fragment (a), for he only reports corrections by Vitelli, unverified by himself, nor does he have any comments on the last three lines of the PSI part that were left unread in the editio princeps. As a result, Edgar was unable to establish the gap between both fragments, which led to their separate line numbering.

Some years ago, photographs of many Zenon papyri housed in Italian collections were published by R. Pintaudi in P. Mostra Zenon. One of the plates (Tav. CXCVIII) shows PSI VII 867, fragment (a) of P. Cair. Zen. I 59014. The picture shows that the last three lines, though not transcribed by either Vitelli or Edgar, are in fact partially legible. In all these lines we recognize remains of $\varphi$ ó $\varepsilon \varepsilon \rho o v$ as well as some individual letters:

(a) 7

$$
8
$$

9

$$
\begin{array}{ccc}
\text { check-mark } \kappa \alpha \text { traces, number } & \varphi \rho \rho \varepsilon \tau .[ \\
\text { traces } & \delta & \varphi \circ \rho \varepsilon \tau \rho[
\end{array}
$$

The first lines of fragment (b) were transcribed as

(b) 1

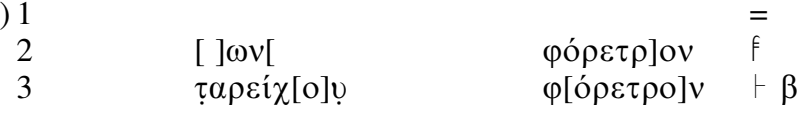

It immediately comes to mind that it is possible that both fragments are continuous and that no text is missing at all. Thanks to the cooperation of W. Clarysse, who provided me with a slide of the Cairo fragment, and R. Pintaudi, who checked the original in Florence, I was able to confirm this.

Although the connection of both parts is not new and although it could suffice to give the new reading of fr. a 1l. 7-8 combined with fr. b. 11. 1-3, the fact that we now know the exact contents of the text justifies a new edition. For we are now also able to see how the calculation of obols was made. Furthermore, we can check the relevant entries in $P$. Cair. Zen. I 59012, which is closely related to this text and P. Cair. Zen. I 59013. 


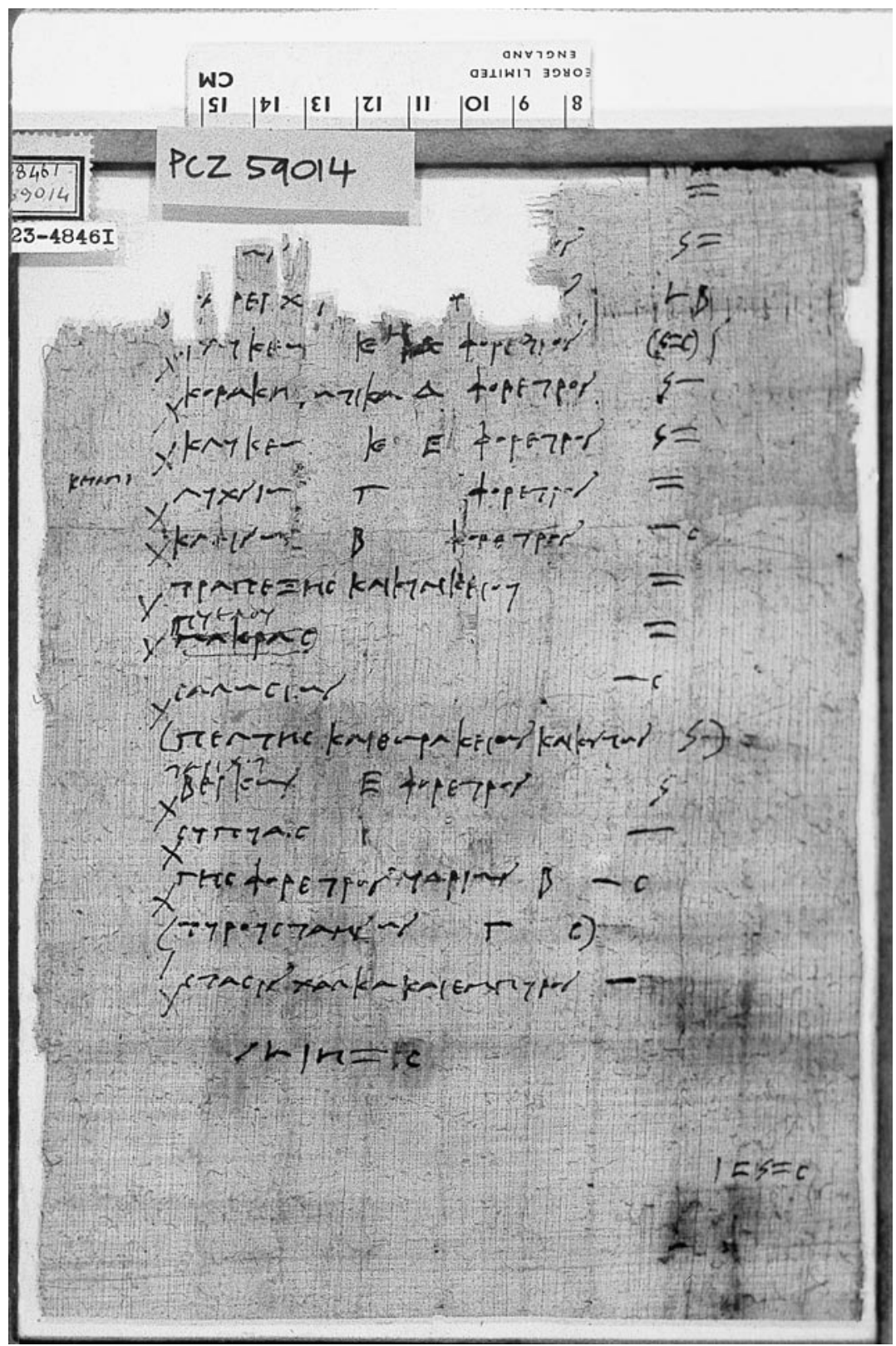


Nature of the text

P. Cair. Zen. I 59014 is a porterage account of goods transported on the boat of Patron and destined for Apollonios the dioicetes. These goods were imports from abroad, arriving in Egypt through Pelousion. This is revealed by $P$. Cair. Zen. I 59012, a long list concerning the taxation of these and other imported goods, which were transported on the vessels of Patron and Herakleides and meant not only for Apollonios, but for two other persons as well ${ }^{6}$. P. Cair. Zen. I 59013 is the porterage account of the goods for Apollonios transported by Herakleides. It is written in the same hand as 59014 ${ }^{7}$. Both texts enabled Edgar to reconstruct much of the lost part of P. Cair. Zen. I 59012, col. I and II, which concern the same items as 59013 and 59014. Similar porterage accounts must have been made for the two other beneficiaries of the imported products. Both 59013 and 59014 have check-marks, written somewhat lower than the entries to which they belong, and looking like a large chi. Some entries are deleted, sometimes corrections are added. Both texts have additions in the margin. In both texts we find items that are not listed in the taxation list P. Cair. Zen. I 59012. Some of these items are pieces of furniture, others are imported food. Apparently they were not subject to taxation, presumably because they were meant for private use and consumption. P. Cair. Zen. I 59013 and 59014 were written in a skilled hand, but by someone who had some difficulties with orthography. The most remarkable mistakes the writer has made are the replacement of $\sigma$ and $\zeta$ by $\xi$ in o $\xi o v \xi$ in 59013.11 and $\tau \rho \alpha \pi \varepsilon \xi \eta \varsigma$ in 59014.15.

\section{Text}

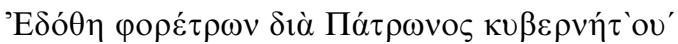

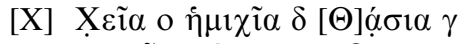

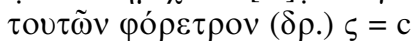

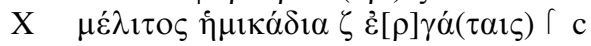

\footnotetext{
${ }^{6}$ For P. Cair. Zen. I 59012 see H. Chouliara-Raios, L'abeille et le miel en Egypte d'après les papyrus grecs, Iannina 1996, p. 74-75, and the literature cited there, n. 163. Cf. also A. ANDRÉADES, in Mélanges Gustave Glotz I, Paris 1932, p. 7-48. Reprints with translations and discussions of $P$. Cair. Zen. I 59012-59014 have been recently published by X. Durand, Des Grecs en Palestine au III siècle avant Jésus-Christ, Paris 1997, texts 12-14.

${ }^{7}$ A plate of P. Cair. Zen. I 59013 is available in the ed.pr., Pl. III, and in R. SEIDER, Paläographie der griechischen Papyri III.1, Stuttgart 1990, p. 177. Seider suggests (p. 176) that it was written by Herakleides himself. Since Patron's account is in the same hand, this does not seem likely.
} 


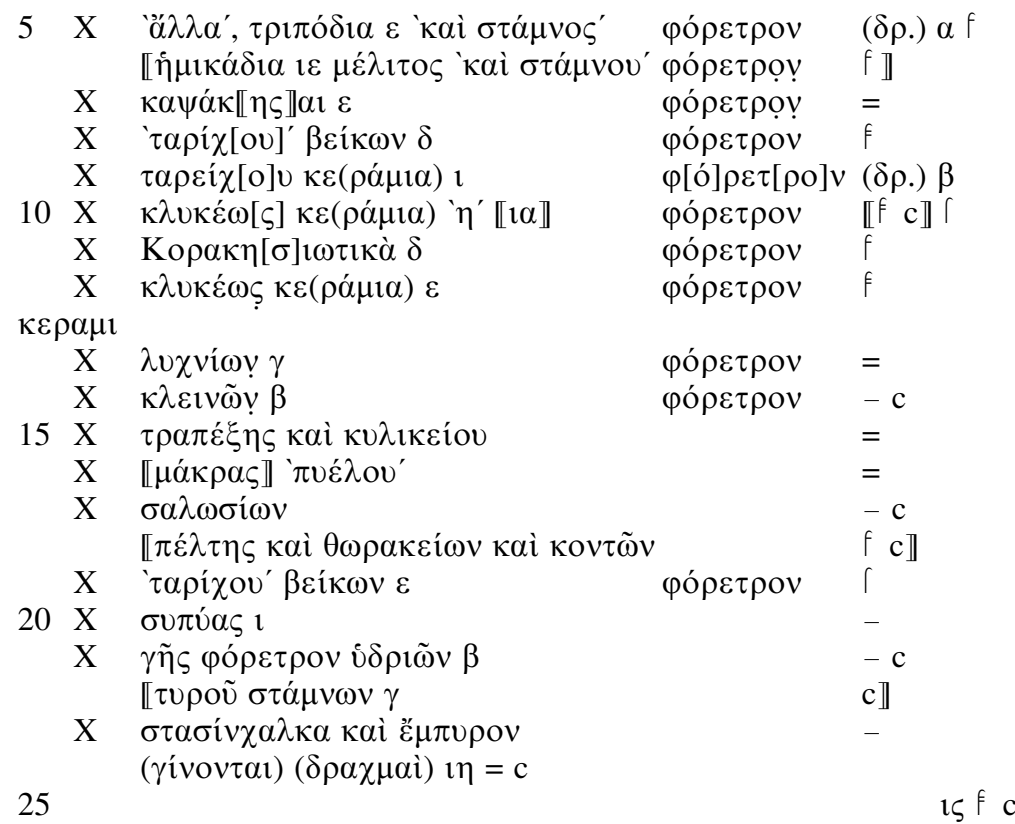

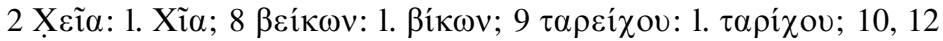

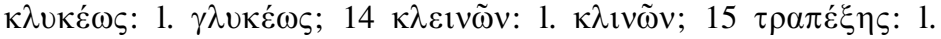

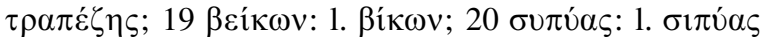

\section{Translation}

Has been given for porterage by Patron the shipper:

70 Chian jars, 4 half-Chian jars, 3 Thasian jars,

their porterage

6 dr. 2.5 ob.

7 half-jars of honey for the workmen

$3.5 \mathrm{ob}$.

5 'others', tripods 'and a stamnos'

【15 half-jars of honey 'and for a stamnos'

5 kapsakai

for 4 bikia of pickled fish

10 jars of pickled fish

$8 \llbracket 11 \rrbracket$ jars of sweet wine

4 jars from Korakesios

1 dr. 4 ob.

$\begin{array}{ll}\text { porterage } & 1 \mathrm{dr} .4 \\ \text { porterage } & 4 \mathrm{ob} . \rrbracket\end{array}$

porterage $2 \mathrm{ob}$.

porterage $5 \mathrm{ob}$.

porterage $2 \mathrm{dr}$.

5 jars of sweet wine

porterage $3 \llbracket 5.5 \rrbracket \mathrm{ob}$.

for 3 lamps

porterage $4 \mathrm{ob}$.

for 2 beds

porterage $5 \mathrm{ob}$.

porterage $2 \mathrm{ob}$.

for a table and and a sideboard

porterage $1.5 \mathrm{ob}$.

for a «bathtub》 'bathtub'

2 ob.

for salousia

2 ob.

【for a shield and cuirasses and goads

$1.5 \mathrm{ob}$.

4.5 ob. 


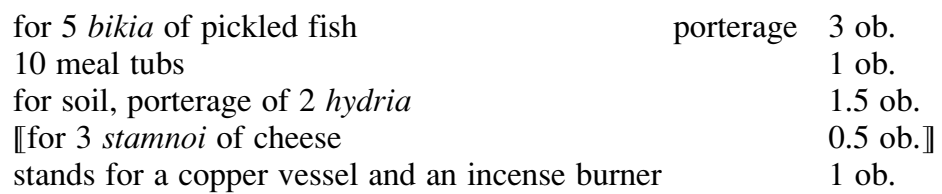

(total of all items: 9 dr. +56 ob. $=18$ dr. 2 ob.)

total 18 dr. $2.5 \mathrm{ob}$.

16 dr. 5.5 ob.

\section{Commentary}

A final proof that the text is complete can be obtained from the total of drachmai and obols in 11. 24-25. The total in 1.24 is the total of all items in the list, including those that have been cancelled, and there is a miscalculation of only $1 / 2 \mathrm{ob}$; the exact amount should be $18 \mathrm{dr}$. $2 \mathrm{ob}$. The total of 1.25 is the total of all entries with a check-mark, i.e $18 \mathrm{dr}$., 2 1/2 ob. minus $9 \mathrm{ob}$., the porterage of the cancelled entries; the correction to the amount in 1.10 from $51 / 2 \mathrm{ob}$. to $3 \mathrm{ob}$. is overlooked. Thus, the text was written in different stages. First a list was made (based on P. Cair. Zen. I 59012?) of several items and their porterage. The total was made up and registered at the bottom. Then, it was marked which of them was actually transported. They were counted and some items were deleted from the list or added to it. Check-marks were added in front of the entries and the new total of dues was written on the right in 1.25 . It seems that the scribe who initially wrote the list also checked and altered it. The handwriting of the added items is similar to the original entries and the new total of 1.25 shows the same rectangular stigma that is also written in 1. 3 and P. Cair. Zen. I. 59013.6 ${ }^{8}$.

Virtually all entries concerning food and wine in $P$. Cair. Zen. I 59013 and 59014 correspond with the items listed in P. Cair. Zen. I 59012 as belonging to Apollonios and transported on the boats of Herakleides and Patron. The following table will illustrate this for the wine, honey and fish of both cargoes and the other products of 59014, at the

${ }^{8}$ For the epigraphical appearance of the numbers in these texts cf. below, comm. on 1. 5. According to R. SEIDER, op. cit. (n. 7), p. 180, the second list in the margin of P. Cair. Zen. I 59013 was written by a second hand. It rather seems that the lack of space obliged the writer/controller of the list to use a different, smaller, type of writing than he used in the main text, cf. Edgar's qualification of the writing in the ed.pr. 
same time showing their value, dues for diapylion (registered at the left of the entries in 59012) and mean porterage per unit:

\begin{tabular}{|c|c|c|c|c|c|}
\hline P. Cair. Zen. I 59012 & P. Cair. Zen. I 59013 & P. Cair. Zen. I 59014 & $\begin{array}{l}\text { porterage } \\
\text { (average) }\end{array}$ & diapylion & $\begin{array}{l}\text { value in } \\
\text { timesis }\end{array}$ \\
\hline \multicolumn{6}{|l|}{ wine: } \\
\hline (22) $\mathrm{Xĩ}[\alpha \quad 61]$ & (2) Xeĩ 61 & & $1 / 2 \mathrm{ob}$. & 3 ob. & $18 \mathrm{dr}$. \\
\hline (17) $\mathrm{Xĩ}[\alpha 70$ & 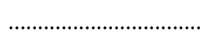 & (2) $\mathrm{X} \varepsilon i \tilde{\alpha} 70$ & $1 / 2 \mathrm{ob}$. & 3 ob. & $18 \mathrm{dr}$. \\
\hline (18) $\dot{\eta} \mu 1 \chi \tilde{\imath} \alpha[4$ & $\ldots$ & (2) $\dot{\eta} \mu \iota \tilde{\imath} \alpha{ }^{4}$ & $1 / 4 \mathrm{ob}$. & $1.5 \mathrm{ob}$ & [9 dr.] \\
\hline 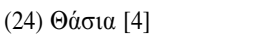 & 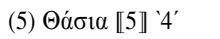 & & $3 / 4 \mathrm{ob}$. & 3 ob. & $20 \mathrm{dr}$. \\
\hline 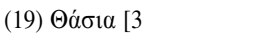 & $\ldots$ & (2) $\Theta \alpha ́ \alpha \_1 \alpha 3$ & $3 / 4 \mathrm{ob}$. & [3 ob.] & [20 dr.] \\
\hline (10) ő & $\begin{array}{l}\text { (11) ő̧ovs } \\
\kappa \varepsilon(\rho \alpha ́ \mu 1 \alpha) \llbracket 4 \rrbracket 2\end{array}$ & . & $1 \mathrm{ob}$. & 3 ob. & $3 \mathrm{dr}$. \\
\hline 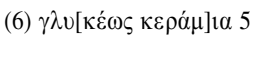 & 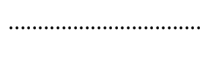 & 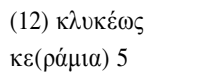 & $1 \mathrm{ob}$. & 3 ob. & $12 \mathrm{dr}$. \\
\hline \multicolumn{2}{|c|}{ 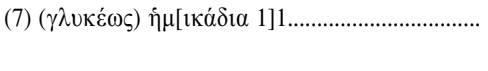 } & (10) $\kappa \lambda \cup \kappa \varepsilon ́ \omega \varsigma$ & $\llbracket 1 / 2 \rrbracket$ & [2 ob.] & $4 \mathrm{dr}$. \\
\hline (11) $[\gamma \lambda \cup \kappa \varepsilon \dot{\varepsilon} \omega \varsigma \dot{\eta} \mu .4]$ & $\begin{array}{l}\text { (10) } \gamma \lambda \cup \kappa \varepsilon \dot{\varepsilon} \omega \varsigma \\
\dot{\eta} \mu 1 \kappa \alpha ́ \delta 1 \alpha 4\end{array}$ & $\kappa \varepsilon(\rho \dot{\mu} \mu t \alpha) \llbracket 11 \rrbracket 8$ & $\begin{array}{l}3 / 8 \text { ob. } \\
1 / 2 \text { ob. }\end{array}$ & [2 ob.] & $4 \mathrm{dr}$. \\
\hline
\end{tabular}

honey:

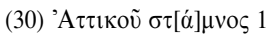

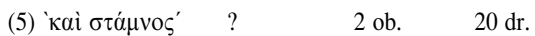

(28) $\mu \varepsilon \dot{\lambda} \iota \tau \circ \varsigma \Theta \varepsilon \alpha \gamma \gamma \varepsilon \lambda \iota \kappa o \tilde{~}$

(4) $\mu \varepsilon \dot{\lambda} \lambda \tau$ เ

2 ob. $\quad 12 \mathrm{dr}$.

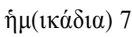

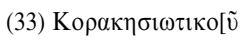

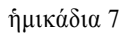
$\hat{\eta} \mu(1 \kappa \alpha ́ \delta 1 \alpha) 4$

(11) Коракп- $1 \mathrm{ob} . \quad 2$ ob. $\quad$ [12 dr.]

(34) X $\alpha \lambda \cup \beta \omega v i ́ o v \kappa \alpha[\psi \alpha ́ \kappa \alpha 15$ $[\sigma] \iota \omega \tau \iota \kappa \grave{\alpha} 4$

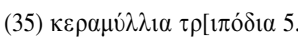

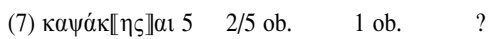

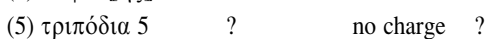

fish:

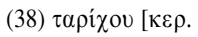

(39) ஸраíov $[\kappa \varepsilon \rho$.

(9) $\tau \alpha \rho \varepsilon i ́ \chi[o] v$ $\kappa \varepsilon(\rho a ́ \mu 1 \alpha) 10$

$11 / 5$ ob. $1 \mathrm{dr}$ ? ?

(40) $\dot{i} \pi[0 \gamma \alpha \sigma \tau \rho i \omega v \kappa \varepsilon \rho$.

(8) $\tau \alpha \rho i ́ \chi[o v]$

$11 / 4 \mathrm{ob}$.

$11 / 4 \mathrm{dr} . \quad \geq 20 \mathrm{dr}$.

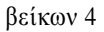

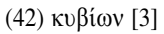

(19) $\tau \alpha \rho i ́ \chi o v$

3/5 ob. $\quad 1 \mathrm{dr}$. $16 \mathrm{dr}$.

(43) $\sigma \varphi \eta v \varepsilon \dot{\varepsilon} \omega \nu$ [2]

$\beta \varepsilon i ́ \kappa \omega v 5$

$12 \mathrm{dr}$.

cheese, meat and Samian earth:
(36) $\tau v \rho \llbracket . \rrbracket o \tilde{~ X ̣ i ́ o v ~}$

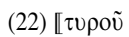
$1 / 6$ ob.
no charge $5 \mathrm{dr} . ?$, cf.

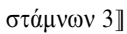
012.57
(44) $\kappa \rho \varepsilon \tilde{\omega} \nu \sigma[v \alpha] \gamma \rho \dot{\varepsilon} \omega \nu$
(17) $\sigma \alpha \lambda \omega \sigma i \omega v$
3/4 ob.
no charge $2 \mathrm{dr}$.
$\sigma \alpha \lambda \circ{ }^{\prime}(\sigma \iota \alpha) 2$
(45) $\gamma \tilde{\eta} \varsigma \Sigma \alpha \mu \dot{i}_{\alpha} \sigma \tau \alpha \dot{\mu} \mu \nu o 12$

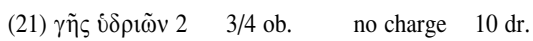

9 A similar comparison of all items listed in P. Cair. Zen. I 59013 and their counterparts in 59012 can be found in N. KRUIT - K.A. WORP, APF 46.1, §3.1 s.v. Кораки́- 
The method of registering in P. Cair. Zen. I 59012 can be seen in the nearly completely preserved $11.81-86$ :

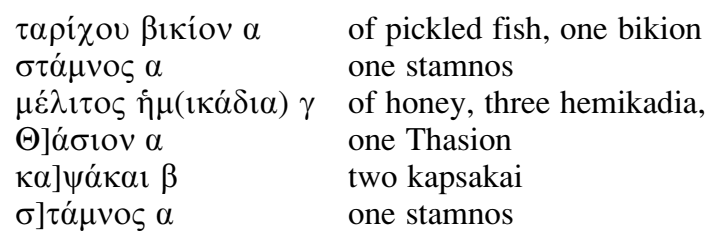

Thus, if only the kind of container changes, the product is not mentioned, if the product changes, the new product and the container holding it are mentioned. We also see that there is no firm relation between the porterage, diapylion and value of the imported goods. One would expect that if a keramion of sweet wine is valued at $12 \mathrm{dr}$., charged $3 \mathrm{ob}$. for diapylion and $1 \mathrm{ob}$. for porterage, a hemikadion would be valued at 6 dr., paying $11 / 2$ ob. for diapylion and 1/2 ob. for porterage. However, only the last figure is correct: for diapylion 2 ob. are due, while its value is set at only $4 \mathrm{dr}^{10}$. Edgar already noted that the keramion and hemikadion seemed to have a fixed rate for the diapylion, regardless of the value of their contents. A keramion is charged at $3 \mathrm{ob}$., a hemikadion at $2 \mathrm{ob}$. He also noted that in some cases, the high value of the content of a small container, such as the stamnos of white oil, valued at $20 \mathrm{dr}$., could render the stamnos liable to the diapylion as well, whereas other stamnoi holding less valuable products (e.g. the stamnoi of Chian and other cheese) were exempted from the diapylion. In general, the amount of money paid for porterage is a fraction of the money paid for diapylion. However, the items which are exempted from the diapylion are not exempted from paying porterage, cf. again the stamnoi of cheese.

With this in mind, we can understand some entries better. Edgar could not fill all the lacunae in 11. 28-45 of P. Cair. Zen. I 59012, for he did not have the whole text of P. Cair. Zen. I 59014. He could not know of the 5 kapsakai of honey, the 10 keramia of pickled fish and the 4 bikia of the same product, all recorded in the previously unread lines of the Florentine fragment. It is evident that the 5 kapsakai are those of 59012.34,

$\sigma \iota \mathrm{ov} / \mathrm{Ko \rho \alpha \kappa \eta \sigma \iota ๘ \tau \iota \kappa óv.} \mathrm{Some} \mathrm{of} \mathrm{the} \mathrm{correspondences} \mathrm{presented} \mathrm{in} \mathrm{the} \mathrm{chart} \mathrm{below} \mathrm{are}$ based on new restorations/interpretations of P. Cair. Zen. I 59012, which will be accounted for below. For a discussion of the various kinds of honey that are listed in 59012 and 59014 see H. ChOUliara-Raios, op. cit. (n. 6), p. 74-83.

${ }^{10}$ Only in 1.92 is the diapylion for a hemikadion of sweet wine the expected $11 / 2$ ob./hemikadion, but there it is also valued at $4 \mathrm{dr}$. 


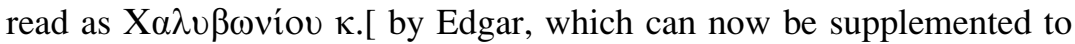

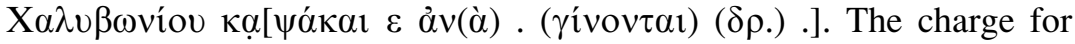
diapylion recorded in front of this entry is $5 \mathrm{ob}$., thus $1 \mathrm{ob} . /$ kapsakes. In all likelihood, we therefore have to supplement $[=\kappa \alpha] \psi \alpha ́ \alpha \alpha \iota \beta$ in 1.85 and thus $[f \Theta]$ ó $f$ iov in 1.84 in order to reach the total of $3 \mathrm{dr}$. of diapylion for 11. 81-86 as recorded in 1. $88^{11}$. The kapsakai of 1.85 are valued at $8 \mathrm{dr}$. and this could also be the value of the Chalubonian honey. The entries for pickled fish are grouped in 59012.38-43. In 1. 41, the kind of container changes into bikia, thereby suggesting that the containers of 11. 38-40 were the 10 keramia. Since the product does not change in 1. 41, one probably has to understand (i $\pi 0 \gamma \alpha \sigma \tau \rho i ́ \omega v) \beta \imath \kappa i ́ \alpha$

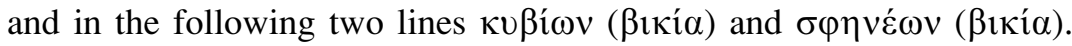
The total of these lines must be 9 bikia. Edgar had supplemented 1. 41

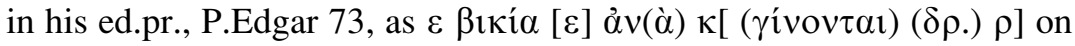

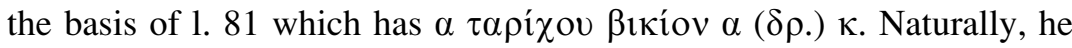
did not adapt his reconstruction of this line once he knew of $P$. Cair.

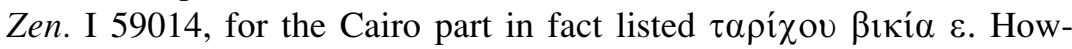
ever, not ordinary pickled fish is meant here, but í rior quality ${ }^{12}$. Furthermore, if 5 bikia worth 20 drachmai is charged for diapylion at $1 \mathrm{dr}$. each, how are we to understand 11. 42-43, where the remaining 4 bikia are valued at 16 and $12 \mathrm{dr}$., but nevertheless paying $5 \mathrm{dr}$. for diapylion. A more likely solution is to read the passage as follows:

$$
\begin{aligned}
& \varepsilon \beta 1 \kappa i ́ \alpha[\delta] \grave{\alpha} v(\grave{\alpha}) \kappa[.(\gamma i ́ v o v \tau \alpha \imath)(\delta \rho .) \text {.(.)] }
\end{aligned}
$$

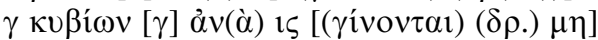

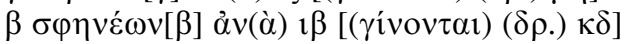

If reconstructed like this, the higher value of the bikia in 1.41 is matched by the higher rate for diapylion and the higher amount of porterage ( $11 / 4 \mathrm{dr}$. and $11 / 4 \mathrm{ob}$. per bikion), whereas the cheaper qualities pay $1 \mathrm{dr}$. and a mean of $3 / 5 \mathrm{ob}$. per bikion ${ }^{13}$. We do not know the division of the 10 keramia of pickled fish in 11. 38-40. One could sup-

11 The stamnos of 1. 86, also preceded by a lacuna, was free of charge, cf. 1. 82.

$12 \mathrm{Cf}$. the discussion of T. ReEKMAns, La consommation dans les archives de Zénon,

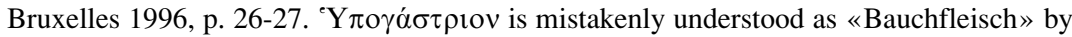
H.-J. DreXHAGE, Einige Bemerkungen zu Fleischverarbeitung und Fleischvertrieb nach den griechischen Papyri und Ostraka vom 3. Jh.v. bis zum 7. Jh.n., MBAH 16.2 (1997), p. 97-111.

${ }_{13}$ Of course, a value of $1 / 5 \mathrm{ob}$. does not exist. The total of $3 \mathrm{ob}$. for porterage of 5 bikia is probably an upwardly rounded total of 3 bikia at x ob. and 2 bikia at y ob., cf. 11 . 2-3 and the commentary on these lines below. 
pose from the known payments of one and four oboloi for diapylion in 11. 38-39 that these lines conceal one keramion of pickled fish and four keramia of tuna fish ${ }^{14}$. This would mean that 1.40 would contain five keramia of fillet. This does not mean automatically that the amount for diapylion in that line should be five drachmai, for we have just seen that the bikia of fillet were probably paying a higher rate for diapylion than the cheaper qualities of pickled fish. Therefore, a higher amount than 5 dr. cannot be excluded for the supposed five keramia of fillet. In fact, this is the only missing entry for diapylion in col. II. In col. III, payments for diapylion could be missing in 11. 56-57, cf. Edgar's remark in the editio princeps. Fortunately, we know the total amount of diapylion for col. I-III, viz. 112 dr., $31 / 4$ ob., 1 chalkos, cf. 1. 75. The total of col. I is $84 \mathrm{dr}$., 1 ob. (1. 28). The total of col. II-III is $19 \mathrm{dr}$., 15 ob. $=21$ dr., 3 ob. for 1l. $28-39+31 / 4$ ob., 1 chalkos for 1l. 41-63. This means that in 11.40 and 56-57 a sum is missing of $112 \mathrm{dr}$., $31 / 4 \mathrm{ob}, 1$ chalkos minus ( 84 dr. 1 ob. +21 dr., 3 ob. $+31 / 4$ ob. 1 chalkos) $=6$ dr., 2 ob. In all likelihood, six dr. are to be restored in 1. 40, leaving two ob. for 11. 56-57. In this way, the five keramia of fillet would pay nearly the same amount of diapylion as the four bikia of the same product (1 $1 / 5$ dr./keramion versus 1 1/4 dr./bikion).

The only entry that is difficult to reconcile with P. Cair. Zen. I 59012 is the corrected 1. 6, which must summarize 59012.29-32:

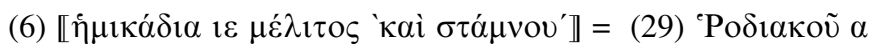

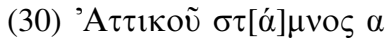

(31) $\Lambda$ икакой

(32) $\dot{\varepsilon} \lambda \dot{\alpha} \sigma \sigma \omega[$

The stamnos of Attic honey is the only item that corresponds exactly. After being added to this line, it was added again to the preceding line after which the whole of 1.6 was cancelled. The cancellation of the addition to 1.6 is marked by the fact that the bracket at the end of the line also extends above the supralinear written кai $\sigma \tau \alpha \dot{\mu} \mu v o v$. Apparently, the total amount of the Rhodian, Lycian and other honey in P. Cair. Zen. I 59012. 29-32 was 15 hemikadia, but the amounts paid for diapylion listed opposite the entries seem to contradict this. The Rhodian honey

14 The rates of porterage for keramia and bikia are similar and therefore it seems reasonable to suspect that the diapylion rates were similar as well. As a result, a keramion of pickled fish would also be charged one dr. for diapylion, just like the bikion of 1. 81 . 
pays the normal rate of a hemikadion viz. 2 obols for diapylion and valued $12 \mathrm{dr}$. The Lycian honey of 1.31 is also only one hemikadion. Thus, the entry of 1.32 would be 13 hemikadia, but the amount due for diapylion is only one drachme, or the levy for three hemikadia. Of course, the information of P. Cair. Zen. I 59014 can be mistaken and the figure ' 15 ' might be wrong. However, there seems to be good reason that although the whole line was cancelled, the items in it are still to be found in the list. As explained above, the stamnos of Attic honey was added to the 5 tripodia in the previous line, and it seems that the 15 hemikadia reappear as the supralinear written $\alpha 2 \lambda \lambda \alpha$. This can be deducted from the rather high payment for porterage, $1 \mathrm{dr}$. 4 ob. For diapylion, the stamnos of Attic honey and the hemikadia of Rhodian and Lycian honey are paying $2 \mathrm{ob}$. each. The 5 tripodia are free of charge. Therefore, one would expect a charge for porterage of $1 / 2 \mathrm{ob}$./hemikadion, just as the hemikadia in 1.4 and probably even a lower figure for the tripodia. The amount due for the stamnos might be $3 / 4 \mathrm{ob}$., cf. the rate for the Thasion of wine, which is equal in value, or the stamnos of Samian earth. If 1.5 was to be understood as «other tripodia, 5, and a stamnos, porterage $1 \mathrm{dr} .4 \mathrm{ob} . »$, both the element 'other' and the high figure of porterage are incomprehensible, since no tripods are preceding and the expected porterage would be only some $31 / 4 \mathrm{ob}$. or less. However, if the word $\alpha \lambda \lambda \lambda \alpha$ is in fact a transposition of the cancelled 15 hemikadia of the line beneath, the whole phrase as well as the figure become understandable. "A $\mathrm{A} \lambda \lambda \alpha$ then should be understood as $\alpha \dot{\alpha} \lambda \alpha$ $\eta \mu \iota \kappa \alpha ́ \delta 1 \alpha$ and the figure would also consist of $71 / 2 \mathrm{ob}$. (or $1 \mathrm{dr}$., $11 / 2$ ob.) porterage for 15 hemikadia. The remaining $21 / 2$ ob. could very well be the charge for the 5 tripodia and the stamnos. Thus, 15 hemikadia indeed may be the correct total of 59012.29, 31 and 32 with 13 hemikadia in that last line.

Yet another clue that this indeed might be the case can be gathered from the total value of all products liable to the $25 \%$ tax rate of col. IIIII, viz. 859 dr., $41 / 2$ ob. (cf. 1. 70). If we add up all numbers that are securely read or reconstructed the total is only $228 \mathrm{dr} .41 / 2$ ob., i.e. 631 dr. less. These $631 \mathrm{dr}$. are the total of 11. 31-43, but some of the amounts in these lines can be reconstructed with probability: the hemikadia of Lycian and Korakesiotic honey probably also valued $12 \mathrm{dr}$. each, the Chalubonian kapsakai could be $8 \mathrm{dr}$. each, the Chian and other cheeses valued each some $5 \mathrm{dr}$. and the 10 keramia and 4 bikia of pickled fish were valued at \pm 20 dr. per unit. For the remaining 5 bikia I have 
suggested a total value of $72 \mathrm{dr}$. The total value of the honey (without the honey of 11.32 and 35) then would be $100 \mathrm{dr}$., that of cheese $15 \mathrm{dr}$. and that of pickled fish some $352-392 \mathrm{dr}^{15}$., or 467-507 dr. in all. We still would be missing 631 minus $(507-467)=124-164 \mathrm{dr}$. which must represent the value of the honey in 11.32 and 35 , thereby suggesting that in 1.32 indeed a substantial number of hemikadia is missing, not just 3 as suggested by the payment for diapylion.

1. $\varphi \rho \rho \varepsilon ́ \tau \rho \omega \nu:$ the word means «porterage», but the amounts registered in this list are not to be understood as the price for carrying the said number of individual jars. Carrying one Chian jar of wine would cost $1 / 2$ ob., cf. the commentary on the next lines, but $1 / 2-1 \mathrm{ob}$. is also the average wage of a workman per day, cf. K. MARESCH, Bronze und Silber. Papyrologische Beiträge zur Geschichte der Währung im ptolemäischen und römischen Ägypten bis zum 2. Jahrhundert n.Chr. (Papyrologica Coloniensia, 25), Opladen 1996, p. 192.

2-3. P. Cair. Zen. I 59013.2 and 5 allow us to reconstruct the calculation that led to the total dues for porterage for Chia, half Chia and Thasia: the amounts for porterage are $1 / 2 \mathrm{ob}$./Chion, thus $1 / 4 \mathrm{ob} . /$ half Chion, and $3 / 4 \mathrm{ob}$./Thasion. The total therefore should be $(70 \times 1 / 2)+(4 \times 1 / 4)$ $+(3 \times 3 / 4)=381 / 4$ ob. $=6$ dr. $21 / 4$ ob., rounded up to 6 dr. $21 / 2 \mathrm{ob}$.

4. $\grave{\varepsilon}[\rho] \gamma \alpha \dot{\alpha}(\tau \alpha \iota \varsigma)$ : conjectured by Edgar (with a dotted $\gamma$ ) in his Intro-

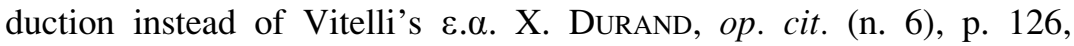
doubted the correctness of Edgar's proposal. However, the plate of the Florentine part of the papyrus clearly shows $\varepsilon[] \gamma \alpha$ and since $P$. Cair.

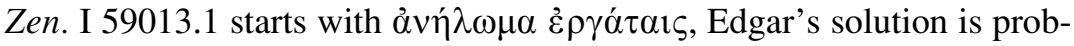
ably right.

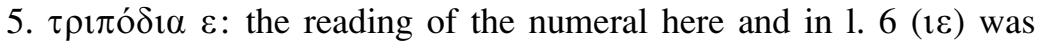
questioned by Vitelli because of the peculiar shape of the $\varepsilon$, looking like a large capital E. Therefore, they were dotted in P. Cair. Zen. I 59014 by Edgar, whereas he read the same numeral without hesitation in the Cairo fragment (b) 6 and 13. The writer of P. Cair. Zen. I 59013-59014 uses archaic, epigraphical types of letters for the numerals, which accounts for their peculiar shapes. See the discussion of A and E by R. SEIDER, op. cit. (n. 7), p. 177-178 and n. 96.

15 The total of $352 \mathrm{dr}$. is made up of 10 keramia and 4 bikia at $20 \mathrm{dr}$. $+72 \mathrm{dr}$. for the 5 bikia of 11. 42-43. An additional $40 \mathrm{dr}$. must be added if the 5 keramia and 5 bikia of fillet were valued higher (at $24 \mathrm{dr}$.), which one would expect from the payments for diapylion and porterage for these jars. 


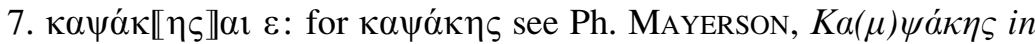
the Papyri, LXX and TLG, BASP 36 (1999), p. 93-9716. Reporting the results of a search in the DDBDP, Mayerson (p. 95) lists the following papyrological attestations:

- Zenon texts

P. Cair. Zen. I 59007 Intr. (кó $\psi$. honey); not in $D D B D P$, see Mayerson p. 96

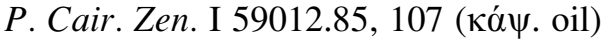

P. Lond. VII 1930.152, 211 (Кó $\psi$. wine)

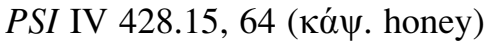

- Other attestations

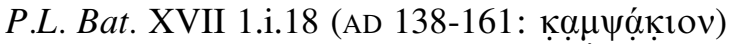

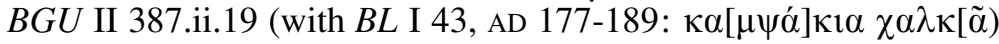

P. Oxy. XX 2273.6 (III AD: Kó $\psi$. oil)

P. Oxy. XXXVI 2784.25 (III AD: no product)

P. Ryl. IV 627.164 (IV AD: Kó $\psi$. oil)

To these may be added:

P. Cair. Zen. I 59012.34 (see the discussion above, Kó $\psi$. honey) and

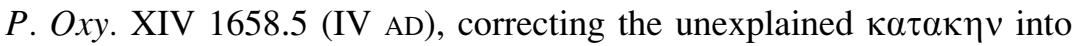
Кó $\psi \alpha \kappa \eta v^{17}$. Lastly, the word occurs in 1.10 of the fourth (?) century AD Coptic papyrus $P$. Mich. Inv. 3552, published in BASP 19 (1982), p. 64-65, kapsakes of oil. Mayerson (p. 96) also mentions a graffito from Dura Europos, an inventory list of temple gifts, mentioning $\kappa \alpha[\psi] \alpha ́ \kappa i \alpha$

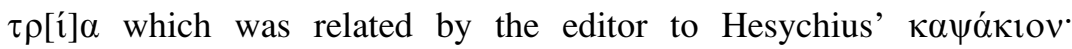
$\gamma \lambda$ not fit the context of the graffito. It appears more likely that a gift was made of three vessels, which may have been of a precious metal as other

16 The term кá $\psi \alpha \kappa \eta \varsigma$ was discussed previously by H. CHOUliaRA-RAIOS, op. cit. (n. 6), p. 124-125 with literature. The relation with Latin capsa has been doubted by D. HAGEDORN in P. Heid. V 333, comm. on 1. 8. As further support of this rejection one may note that кá $\psi \alpha \kappa \eta \varsigma$ is transliterated by late classic and medieval Latin authors as capsaces or capsax, cf. ThLL and DuCange, s.v. The Latin loan word $\kappa \alpha \dot{\alpha}(\mu) \psi \alpha$ «case» and derivatives are attested in the papyri from AD 258 onwards, cf. D. HAGEDORN, l.c. Cf.

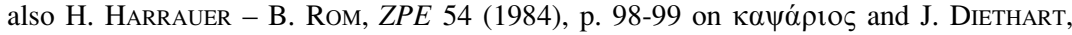
ZPE 64 (1986), p. 78, comm. on 1. 4. For P. Arméno-Grec, cited by J. DieThart, l.c., see now J. ClaCKSON, ZPE 129 (2000), p. 223-258.

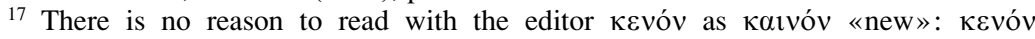
«empty» is perfectly possible and Kalvóv is written correctly in the preceding line, thus arguing against an orthographical mistake in 1. 5 . 
items of gold are mentioned». One may note, however, that P.L. Bat. XVII 1 and $B G U$ II 387, cited above, are temple inventories as well and that $B G U$ II 387.ii.13 also reports $\theta \tilde{\eta} \kappa \alpha 1 \quad \chi \alpha \lambda \kappa \alpha[\tilde{\imath}$ «bronze cases». Therefore, the meaning given by Hesychius, who apparently regards the word as a diminutive of Latin capsa ${ }^{18}$, cannot be excluded a priori. If $\kappa \alpha(\mu) \psi \alpha ́ \kappa i o v$ is to be regarded in these texts as a Latin based word, this would shift the terminus a quo one century back from $258 \mathrm{AD}$ (cf. $\mathrm{n}$. 16 ) to the middle of the second century AD. Of course, the meaning suggested by Mayerson is equally possible. For metal flasks belonging to a church, cf. e.g. P.L. Bat. XXV 13.12 with comm.

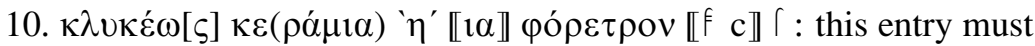
be the equivalent of P. Cair. Zen. I 59012.7 which has $\eta \mu[\imath \kappa \alpha ́ \delta 1 \alpha \iota] \alpha$. The rate for porterage $(1 / 2 \mathrm{ob} / \mathrm{ker}$.) shows that indeed hemikadia are intended, not keramia for which $1 \mathrm{ob} . / \mathrm{ker}$. should be paid, cf. the chart above and 1. 12. A similar 'change' of jars has occurred in 1. 21, where the Samian earth is now in hydria, whereas it was transported in stamnoi in P. Cair. Zen. I 59012. Of course, one would expect that the corrected number of eight keramia $=$ hemikadia would cost four obols for porterage.

13-14. $\kappa \varepsilon \rho \alpha \mu 1:$ I fail to see the purpose of this not finished addition in the left margin.

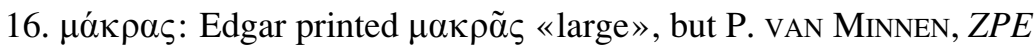

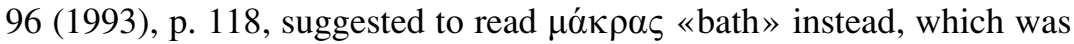
also the meaning listed by LSJ for this passage. It remains unknown why the scribe corrected a word meaning «bath» into another with the same meaning.

17. $\sigma \alpha \lambda \omega \sigma i \omega v$ : two salo(u)sia of meat of boars are meant, cf. $P$.

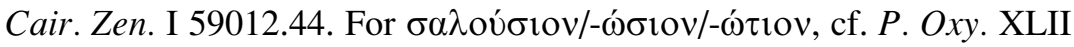
3060, comm. on 1. 8.

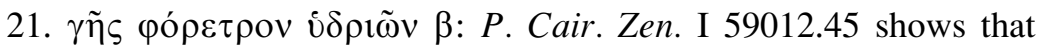
Samian earth was transported. This was used for medical purposes, just like the Attic honey, cf. A. ANDRÉADES, op. cit. (n. 6), p. 15 n. 7. p. 14. 